\title{
Usefulness of the neutrophil-to-lymphocyte ratio to prediction of complications in type 2 diabetes mellitus
}

\section{Tip 2 diabetes mellitusta komplikasyonların öngörüll= mesinde nötrofill-lenfosit oranının yararlılığı}

\author{
Abdullhalim Senyigit
}

Department of Internal Medicine, Istanbul Medicine Hospital, Medical School, University of Biruni, Istanbul, Turkey

Corresponding author: Abdulhalim Senyigit, MD., Department of Internal Medicine, Istanbul Medicine Hospital, Medical School, University of

Biruni, Istanbul, Turkey.

E-mail: abdulhalim.senyigit@medicinehospital.com.tr

Received/Accepted: October 14, 2018 / December 16, 2018

Conflict of interest: There is not a conflict of interest.

\begin{abstract}
SUMMARY
Objective: Increasing evidences show that the concept of type 2 diabetes mellitus (T2DM) as an inflammatory disease has emerged. The aim of the present study was to investigate the role of neutrophil-tolymphocyte ratio (NLR) in T2DM patients comparing with the other well-known inflammatory markers as C-reactive protein (CRP), erythrocyte sedimentation rate (ESR) and fibrinogen. It also investigates usefulness of the NLR to prediction of complications in T2DM.

Method: This study consisted of six patients groups in İstanbul Medicine Hospital between April-October, 2017: It enrolled the laboratory results of 195 subjects of which diabetic group (DM) ( $n=35)$, coronary artery disease $(C A D)$ group $(n=35), C A D+D M$ group $(n=35), D M+$ nephropathy $(n=30), D M+$ neuropathy $(n=30)$, DM+retinopathy $(n=30)$, and 40 healthy controls.

Results: The mean NLR values were significantly higher in all patients than controls. CAD+DM group has the highest NLR values $(4.17 \pm 3.85)$ among the groups. There was no significant difference between the $\mathrm{DM}+$ nephropathy, DM+neuropathy, and DM+retinopathy. The mean NLR values were significantly higher in CAD+ DM group than DM+nephropathy, DM+neuropathy, and DM+retinopathy (for each comparison $\mathrm{p}<0.01)$. There was no statistically significant difference in the mean NLR values between CAD group and CAD+DM group.
\end{abstract}

Conclusions: Results of study demonstrate a possible association of subclinical inflammation with the development of complications in T2DM. NLR is independently associated with other well-known inflammatory markers as CRP, ESR and fibrinogen, inflammation in development of complications in T2DM. NLR values in prediction of complications in T2DM are a useful parameter. During complications of T2DM, NLR may be useful used as an easily measurable, noninvasive, available and cost-effective parameter in clinical practice.

Keywords: Type 2 diabetes mellitus, neutrophil-to-lymphocyte ratio, C-reactive protein, erythrocyte sedimentation rate, fibrinogen. 
Amaç: İnflamatuar bir hastalık olarak tip 2 diabetes mellitus (T2DM) kavramı son zamanlarda ortaya çıkmış ve mevcut kanıtlar ile doğrulanmış gibi görünmektedir. Çalışmanın amacı, T2DM hastalarında nötrofi1lenfosit oranının (NLR) rolünü, C-reaktif protein (CRP), eritrosit sedimantasyon hızı (ESR) ve fibrinojen gibi iyi bilinen diğer inflamatuar belirteçlerle karşılaştırmayı araştırmaktır. Ayrıca T2DM'deki komplikasyonların belirlenmesinde NLR'nin klinik kullanımındaki yararlılı̆̆ı da araştırıldı.

Yöntem: Çalışma, Nisan-Ekim 2017 tarihleri arasında mevcut hastaların oluşturduğu altı gruptan oluşuyordu; Komplikasyonsuz diyabetik grup $(\mathrm{DM})(\mathrm{n}=35)$, koroner arter hastalığı $(\mathrm{KAH})$ grup $(\mathrm{n}=35)$, $\mathrm{KAH}+\mathrm{DM}$ grup $(\mathrm{n}=35), \mathrm{DM}+$ nefropati grup $(\mathrm{n}=30), \mathrm{DM}+$ nöropati grup $(\mathrm{n}=30), \mathrm{DM}+$ retinopati grup $(\mathrm{n}=30)$ ve sağliklı kontrol grup $(\mathrm{n}=40)$.

Bulgular: Ortalama NLR değerleri tüm hastalarda kontrollere göre anlamlı olarak daha yüksek bulundu. KAH+DM grubu, gruplar arasında en yüksek NLR değerlerine (4.17 \pm 3.85$)$ sahiptir. DM+nefropati, $\mathrm{DM}+$ nöropati ve DM+retinopati grupları arasinda anlamlı fark yoktur. $\mathrm{KAH}+\mathrm{DM}$ grubunda ortalama NLR değerleri $\mathrm{DM}+$ nefropati, $\mathrm{DM}+$ nöropati ve $\mathrm{DM}+$ retinopati grubundan anlamlı olarak daha yüksek bulundu (her bir karşılaştırma için $\mathrm{p}<0.01$ ). KAH grubu ile $\mathrm{KAH}+\mathrm{DM}$ grupları arasındaki ortalama NLR değerlerinde istatistiksel olarak anlamlı fark bulunmadi.

Sonuç: Çalışmanın sonuçları, subklinik inflamasyonun T2DM'de komplikasyon gelişimi ile olası bir ilişkisini göstermektedir. NLR, T2DM'de komplikasyonların gelişimindeki inflamasyon, CRP ve fibrinojen gibi iyi bilinen diğer inflamatuar belirteçler ile bağımsız olarak ilişkilidir. T2DM'de komplikasyonların öngörülmesinde NLR düzeyleri yararlı bir parametredir. T2DM'nin komplikasyonları sırasında NLR klinik pratikte kolay ölçülebilir, noninvazif, uygun ve düşük maliyetli bir parametre olarak kullanımı yararlı olabilir.

Anahtar sözcükler: Tip 2 diabetes mellitus, nötrofil-lenfosit oran1, C-reaktif protein, fibrinojen.

\section{INTRODUCTION}

The onset of type 2 diabetes (T2D) leads in turn to the development of its long-term consequences: macrovascular complications (including atherosclerosis and amputations) and microvascular complications (including retinopathy, nephropathy and neuropathy). Insulin resistance is typically present throughout the progression from prediabetes to the later stages of overt T2D. Cross-sectional and prospective studies have described white blood cell count, elevated circulating levels of acute-phase proteins (such as C-reactive protein (CRP), haptoglobin, fibrinogen, plasminogen activator inhibitor and serum amyloid A) and sialic acid, as well as cytokines and chemokines in patients with T2D ${ }^{1}$.

The immune response to various physiological challenges is characterized by increased neutrophil and decreased lymphocyte counts, and the neutrophil-to-lymphocyte ratio (NLR) was defined as a novel potential marker to determine inflammation in many kinds of chronic inflammatory disease including diabetes ${ }^{2-17}$. The count of white blood cell (WBC) is a basic but cheap, readily available, and sensitive indicator of the inflammatory status. WBCs are positively associated with inflammation, particularly in cardiovascular diseases. An increase in the number of neutrophils is associated with thrombus formation and ischemic injury ${ }^{17}$.

The objective of this study was to evaluate the role of NLR as routine parameter in whole blood tests in T2DM patients, comparing with the other well-known inflammatory markers as CRP and fibrinogen. It also investigates usefulness of the NLR to prediction of complications in T2DM.

\section{MATERIAL AND METHODS}

The protocol was approved by the Local ethics Committee and was conducted in accordance with the Declaration of Helsinki. All participants were informed about the survey and voluntarily signed and dated the consent form. The medical histories and physical examination of all participants were obtained.

This study consisted of four patients groups including uncomplicated diabetic patients, patients with diabetic microvascular complications, patients with diabetic macrovascular complicated, patients with cardiovascular disease (CAD) in Hospital between April-October, 2017: It enrolled the laboratory results of 235 subjects of which diabetic group $(\mathrm{DM})(\mathrm{n}=35), \mathrm{CAD}$ group $(\mathrm{n}=35), \mathrm{CAD}+\mathrm{DM}$ group $\quad(n=35), \quad D M+n e p h r o p a t h y \quad(n=30)$, 
$\mathrm{DM}+$ neuropathy $(\mathrm{n}=30), \mathrm{DM}+$ retinopathy $(\mathrm{n}=30)$, and healthy controls $(n=40)$.

DM was diagnosed according to the American Diabetes Association (ADA) criteria ${ }^{18}$ or using oral antidiabetics and/or insulin. Pregnant women, patients with hepatic, rheumatic, malign or endocrine diseases, smokers and subjects who were taking drugs which could affect our results were excluded. Subjects with ocular disease other than diabetic retinopathy were also excluded.

Control group consisted of 40 healthy people from our hospital staff. They did not have diabetes, or glucose intolerance confirmed with oral glucose tolerance test (OGTT). The control subjects had no hepatic, renal, infectious, malign or cardiovascular disease either. All subjects were Turkish descent.

The weight and height of each person were measured and body mass index (BMI) was calculated according to the formula: Weight/height $\left(\mathrm{m}^{2}\right)$. Hypertension was defined as systolic blood pressure $(\mathrm{SBP})>140 \mathrm{~mm} \mathrm{Hg}$, diastolic blood pressure (DBP)> $90 \mathrm{mmHg}$ or current use of antihypertensive medications ${ }^{19}$. Presence of HT, nephropathy, retinopathy (RP), neuropathy (NP) and history about coronary heart disease (CHD), cerebrovascular event (CVE), diabetic foot (DF) were reported.

Blood samples were obtained before drug use in the morning. Samples were collected in EDTAcontaining tubes and anticoagulant-free tubes after an overnight fast. After immediate centrifugation at $3000 \mathrm{~g}$ for 10 minute, at $4{ }^{\circ} \mathrm{C}$, plasma and serum samples were separated. Routine parameters were studied on the same day.

Complete blood count parameters were obtained with automatic hematology analyzer (Abbott Laboratories, Diagnostics Division, Germany). Serum CRP levels were measured by nephelometry (Siemens-Dimention, Germany). Fibrinogen levels were measured with an STA Compact coagulation analyzer (Diagnostica Stago, Inc., Parsippany, NJ, USA)
The other rutin parameters were analyzed according to classic methods using analyzers (Roche Cobas İntegra 400, Roche Diagnostics Ltd. Germany). Insulin concentrations were measured by electrochemiluminescence immunoassay (ECLIA) method on Roche-Hitachi E170 (Roche/Hitachi MODULAR Analytics Combination Systems, Roche Diagnostics, USA). HbA1c determination was based on HPLC (Variant Turbo II, Bio-Rad Laboratories, Inc. USA). HOMA-IR (Homeostatic Model Assessment for Insulin Resistance) was calculated according to the formula: fasting insulin (microU/L) x fasting glucose $(\mathrm{nmol} / \mathrm{L}) / 22.5$.

\section{Statistical analysis}

SPSS (Statistical Package for Social Sciences) for Windows 21.0 package program was used for statistical evaluations. The relationship between the categorical variables of the groups was examined by chi-square test. Descriptive statistics were obtained and data were tested for normality using the Kolmogorov-Smirnov test for Gaussian distribution. For comparison of parameters with normal distribution parametric tests and comparison of parameters with abnormal distribution non- parametric tests were used. For this purpose, One-Way ANOVA, unpaired student- t, Kruskal-Wallis and Mann-Whitney U tests were used. Relationships between variables were assessed with Pearson's or Spearman's correlation coefficient. A $\mathrm{p}$ value equal to or lower than 0.05 was considered statistically significant.

\section{RESULTS}

The demographic, clinical and laboratory findings of the controls and patient with microvascular complication are shown in Table 1. The demographic, clinical and laboratory findings of the controls and patient with microvascular complications.are shown in Table 2. 
Table 1. The demographic, clinical and laboratory findings of patient with microvascular complications.

\begin{tabular}{|c|c|c|c|c|c|}
\hline & $\begin{array}{l}\text { Control } \\
(n=40)\end{array}$ & $\begin{array}{l}\text { Uncomplicated } \\
\text { DM }(n=35)\end{array}$ & $\begin{array}{l}\text { DM+nephropathy } \\
(\mathrm{n}=30)\end{array}$ & $\begin{array}{l}\text { DM+neuropathy } \\
(\mathrm{n}=\mathbf{3 0})\end{array}$ & $\begin{array}{l}\text { DM+retinopathy } \\
(\mathbf{n}=30)\end{array}$ \\
\hline Age (years) & $41.55 \pm 9.77$ & $51.62 \pm 10.11^{\mathrm{c}}$ & $61.67 \pm 14.22^{\mathrm{c}, \mathrm{e}}$ & $62.19 \pm 9.47^{\mathrm{ce}}$ & $62.73 \pm 8.03^{c}$ \\
\hline BMI $\left(\mathrm{kg} / \mathrm{m}^{2}\right)$ & $24.14 \pm 3.65$ & $33.14 \pm 6.41$ & $32.87 \pm 6.78$ & $33.52 \pm 6.03$ & $30.99 \pm 5.28$ \\
\hline $\begin{array}{l}\text { FBG } \\
(\mathrm{mg} / \mathrm{dL})\end{array}$ & $90.28 \pm 6.47$ & $137.66 \pm 48.51^{\mathrm{a}}$ & $155.80 \pm 85.93^{c}$ & $160.18 \pm 77.69^{c}$ & $177.58 \pm 61.26^{\mathrm{c}}$ \\
\hline HbA1c (\%) & $5.59 \pm 0.30$ & $7.10 \pm 1.62$ & $7.43 \pm 1.81$ & $11.37 \pm 18.00^{\mathrm{b}}$ & $8.68 \pm 2.13$ \\
\hline HOMA-IR & $3.33 \pm 1.88$ & $5.35 \pm 3.85$ & $9.17 \pm 17.76$ & $9.80 \pm 21.75$ & $6.42 \pm 7.76$ \\
\hline $\begin{array}{l}\text { PLT } \\
\left(10^{3} / \mu \mathrm{L}\right)\end{array}$ & $233.57 \pm 44.13$ & $239.25 \pm 57.19$ & $244.20 \pm 54.47$ & $241.23 \pm 60.80$ & $252.80 \pm 73.91$ \\
\hline $\begin{array}{l}\text { WBC } \\
\left(10^{3} / \mu \mathrm{L}\right)\end{array}$ & $6.47 \pm 1.44$ & $6.97 \pm 1.60$ & $8.21 \pm 2.63$ & $7.68 \pm 2.16$ & $7.43 \pm 2.56$ \\
\hline $\begin{array}{l}\text { Neutrophil } \\
\text { count } \\
\left(\times 10^{9} / \mathrm{L}\right) \\
\end{array}$ & $3.54 \pm 1.16$ & $4.00 \pm 1.23$ & $5.01 \pm 2.05$ & $4.94 \pm 2.08$ & $4.454 \pm 1.65$ \\
\hline $\begin{array}{l}\text { Lymphocyte } \\
\text { count } \\
\left(\times 10^{9} / \mathrm{L}\right)\end{array}$ & $3.46 \pm 7.38$ & $2.25 \pm 0.65$ & $2.18 \pm 0.64$ & $2.11 \pm 0.52$ & $1.94 \pm 0.50$ \\
\hline NLR & $1.62 \pm 0.62$ & $1.97 \pm 1.17$ & $2.59 \pm 1.48$ & $2.49 \pm 1.26$ & $2.48 \pm 1.34$ \\
\hline $\begin{array}{l}\text { CRP } \\
(\mathrm{mg} / \mathrm{dL})\end{array}$ & $2.51 \pm 2.23$ & $4.51 \pm 5.30$ & $18.58 \pm 28.03$ & $10.76 \pm 13.35$ & $12.07 \pm 31.02$ \\
\hline $\begin{array}{l}\text { Fibrinogen } \\
(\mathrm{mg} / \mathrm{mL})\end{array}$ & $3.11 \pm 0.59$ & $3.19 \pm 0.57$ & $3.82 \pm 0.68^{\mathrm{b}, \mathrm{e}}$ & $3.55 \pm 0.90$ & $3.52 \pm 0.72$ \\
\hline
\end{tabular}

BMI; Body mass index, DM; Diabetes mellitus, FBG; Fasting blood glucose, HbA1c; Hemoglobin A1c, PLT; Platelet, WBC; White blood count,

NLR; neutrophil-to-lymphocyte ratio, CRP: C-reactive protein.

Comparision with control group ${ }^{\mathrm{a}} \mathbf{p}<0.05,{ }^{\mathrm{b}} \mathbf{p}<0.01,{ }^{\mathrm{c}} \mathbf{p}<0.001$

Comparision with uncomplicated DM group ${ }^{\mathrm{d}} \mathbf{p}<0.05,{ }^{\mathrm{e}} \mathbf{p}<0.01,{ }^{\mathrm{f}} \mathbf{p}<0.001$

Comparision with nephropathy DM group ${ }^{\mathrm{g}} \mathbf{p}<0.05,{ }^{\mathrm{h}} \mathbf{p}<0.01,{ }^{\mathrm{k}} \mathbf{p}<0.001$

Comparision with neuropathy DM group ${ }^{\mathrm{m}} \mathbf{p}<0.05,{ }^{\mathrm{n}} \mathbf{p}<0.01,{ }^{\circ} \mathbf{p}<0.001$.

Table 2. The demographic, clinical and laboratory findings of patient with macrovascular complications.

\begin{tabular}{|c|c|c|c|c|}
\hline & $\begin{array}{c}\text { Control } \\
(n=40)\end{array}$ & $\begin{array}{c}\text { Uncomplicated DM } \\
(\mathrm{n}=35)\end{array}$ & $\begin{array}{c}\text { CAD } \\
(\mathrm{n}=35)\end{array}$ & $\begin{array}{c}\text { CAD+DM } \\
(\mathrm{n}=35)\end{array}$ \\
\hline Age (years) & $41.55 \pm 9.77$ & $51.62 \pm 10.11^{\mathrm{b}}$ & $60.17 \pm 13.50^{\mathrm{bh}}$ & $62.61 \pm 11.82^{\mathrm{b}}$ \\
\hline BMI $\left(\mathrm{kg} / \mathrm{m}^{2}\right)$ & $24.14 \pm 3.65$ & $33.14 \pm 6.41$ & $29.74 \pm 4.34$ & $31.22 \pm 6.72$ \\
\hline FBG (mg/dL) & $90.28 \pm 6.47$ & $137.66 \pm 48.51$ & $101.69 \pm 13.91$ & $138.31 \pm 63.56$ \\
\hline HbA1c (\%) & $5.59 \pm 0.30$ & $7.10 \pm 1.62^{\mathrm{b}}$ & $5.59 \pm 0.32$ & $7.34 \pm 1.52^{\mathrm{c}, \mathrm{p}}$ \\
\hline HOMA-IR & $3.33 \pm 1.88$ & $5.35 \pm 3.85^{\mathrm{c}}$ & $6.08 \pm 5.60^{\mathrm{c}}$ & $9.97 \pm 27.26^{\mathrm{c}, \mathrm{m}}$ \\
\hline PLT $\left(10^{3} / \mu \mathrm{L}\right)$ & $233.57 \pm 44.13$ & $239.25 \pm 57.19^{a}$ & $214.43 \pm 51.08$ & $230.72 \pm 70.00^{\mathrm{a}}$ \\
\hline WBC $\left(10^{3} / \mu \mathrm{L}\right)$ & $6.47 \pm 1.44$ & $6.97 \pm 1.60$ & $9.07 \pm 4.48^{\mathrm{a}, \mathrm{b}}$ & $8.22 \pm 1.97^{\mathrm{a}, \mathrm{b}}$ \\
\hline $\begin{array}{l}\text { Neutrophil count } \\
\left(\times 10^{9} / \mathrm{L}\right)\end{array}$ & $3.54 \pm 1.18$ & $4.00 \pm 1.23^{\mathrm{b}}$ & $6.25 \pm 4.01^{\mathrm{b}}$ & $5.36 \pm 1.58^{\mathrm{e}}$ \\
\hline $\begin{array}{l}\text { Lymphocyte count } \\
\left(\times 10^{9} / \mathrm{L}\right)\end{array}$ & $3.46 \pm 7.49$ & $2.25 \pm 0.65$ & $1.84 \pm 1.04^{\mathrm{b}}$ & $1.89 \pm 0.71$ \\
\hline NLR & $1.62 \pm 0.62$ & $1.97 \pm 1.17$ & $3.29 \pm 1.78^{\mathrm{d}}$ & $4.17 \pm 3.85^{\mathrm{g}}$ \\
\hline CRP (mg/dL) & $2.51 \pm 2.23$ & $4.51 \pm 5.30^{\mathrm{a}}$ & $25.67 \pm 48.99^{\mathrm{d}}$ & $18.57 \pm 23.24^{\mathrm{g}, \mathrm{n}}$ \\
\hline Fibrinogen $(\mathrm{mg} / \mathrm{mL})$ & $3.11 \pm 0.59$ & $3.19 \pm 0.57^{\mathrm{a}}$ & $3.63 \pm 0.75^{\mathrm{a}}$ & $3.67 \pm 0.74^{\mathrm{a}}$ \\
\hline
\end{tabular}

BMI; Body mass index, DM; Diabetes mellitus, FBG; Fasting blood glucose, HbA1c; Hemoglobin A1c, PLT; Platelet, WBC; White blood count,

CRP: C-reactive protein.

Comparision with control group ${ }^{\mathrm{a}} \mathbf{p}<0.05,{ }^{\mathrm{b}} \mathbf{p}<0.0001,{ }^{\mathrm{c}} \mathbf{p}<0.001,{ }^{\mathrm{d}} \mathbf{p}<0.006,{ }^{\mathrm{e}} \mathbf{p}<0.01{ }^{\mathrm{f}} \mathbf{p}<0.005$

Comparision with uncomplicated DM group ${ }^{\mathrm{g}} \mathbf{p}<0.01,{ }^{\mathrm{h}} \mathbf{p}<0.05,{ }^{\mathrm{k}} \mathbf{p}<0.0001$

Comparision with CAD group ${ }^{\mathrm{m}} \mathbf{p}<0.01,{ }^{\mathrm{n}} \mathbf{p}<0.05,{ }^{\mathrm{p}} \mathbf{p}<0.001$ 
The mean NLR values were significantly higher in all patients than controls. CAD+DM group has the highest NLR values $(4.17 \pm 3.85)$ among the groups. There was no significant difference between the DM+nephropathy, DM+neuropathy, and DM+retinopathy. The mean NLR values were significantly higher in CAD+ DM group than DM+nephropathy, DM+neuropathy, and

\section{DISCUSSION}

The ratio of absolute neutrophil count to absolute lymphocyte count NLR is a crucial marker of systemic inflammation ${ }^{20}$. The present study demonstrated that the mean NLR values were significantly higher in all patients than controls. CAD+DM group has the highest NLR values among the groups. The mean NLR values were significantly higher in CAD+ DM group than DM+nephropathy, DM+neuropathy, and DM+retinopathy. NLR may be considered as a new inflammatory marker for assessment of inflammation in the existence of T2DM (in patients with especially macrovascular complications) with its quick, easily measurable, noninvasive, available and cost-effective property with routine complete blood count analysis.

Several study showed that NLR among subjects with retinopathy was significantly higher than among diabetic patients without retinopathy ${ }^{9,21-24}$. Fawwad et al. ${ }^{21}$ found that the NLR was 1.14 times higher in diabetic subjects with at least one microvascular complication as compared to diabetic subjects without any complications. Based on the results of their study NLR was considered as an essential and stable marker in diagnosing microvascular diabetic complications. NLR was also significantly higher in patients with nephropathy than in patients without nephropathy. Öztürk et al. ${ }^{14}$ reported that increased NLR levels may be associated with microvascular complications of DM and NLR was an independent associate of retinopathy and nephropathy in the elderly population. Contrary to all these results, in our study, there was no significant difference between the DM+nephropathy, DM+neuropathy, and DM+retinopathy. Our results are similar; Ciray et al. ${ }^{7}$ found that NLR was not significantly different in patients with and without diabetic retinopathy. Moreover, in contrast to nephropathy, NLR was not an independent associate of diabetic retinopathy. Our results seem more consistent because NLR, CRP, ESR and fibrinogen was not associated with presence of microvascular complication. Consequently larger studies with adequate control of known determinants of NLR
DM+retinopathy (for each comparison $\mathrm{p}<0.01$ ). There was no statistically significant difference in the mean NLR values between CAD group and $\mathrm{CAD}+\mathrm{DM}$ group.

NPL level of the groups showed no correlation with any parameters including CRP, WBC, and fibrinogen. There was also no correlation between other parameters.

are required to better elucidate with relationship between diabetic microvascular complications and NLR ${ }^{7}$.

Increased NLR is associated with severe, extensive and complex CAD $(6,25)$. Tanındı et al. 25 showed that NLR is also associated with impaired myocardial perfusion in acute coronary syndrome (ACS), and may be useful for earlier risk stratification and for intensifying the atherosclerosis treatment in higher risk patients. However, in some conditions including traditional risk factors (ie, hypertension, obesity, atherogenic lipoproteins and hyperglycemia) and left ventricular dysfunction or hypertrophy, valvular heart disease, abnormal thyroid function tests and hepatic dysfunction the measurement of NLR can be potentially affected ${ }^{26}$. There were significant differences between the groups regarding the diabetes mellitus, hypertension, hypercholesterolemia and the drug usage (Statin, ACE inhibitor) ${ }^{27}$.

Chittawar et al. ${ }^{24}$ showed that patients in higher NLR quartiles had significantly higher diabetes duration, occurrence of CAD and NLR is inexpensive, easy to use, reliable predictor of nephropathy, retinopathy, and CAD in Indian T2DM. Gabbasov et al. ${ }^{28}$ evaluated whether the occurrence of restenosis is associated with NLR in patients with T2DM after drug-eluting stent (DES) implantation for stable CAD. They found that elevated NLR may serve as an independent predictor of in-stent restenosis in DES in patients with T2DM and elevated NLR is a characteristic of inflammation. They demonstrate that in patients with T2DM and in-stent restenosis in DES, NLR is elevated even more than in the general population with restenosis. Kim et al. ${ }^{29}$ found that both NLR and T2DM were independent prognostic factors significantly associated with significant CAD and that NLR and T2DM added significant incremental value compared with that furnished by conventional cardiovascular risk factors including age, gender, smoking status, HDL cholesterol, and hemoglobin. Also, T2DM patients with high NLR had the greatest prevalence of significant CAD and carotid artery atherosclerosis. Their results 
suggest an additive impact possibly contributed by T2DM together with high inflammatory state on the development of systemic atherosclerosis. Verdoia et al. ${ }^{30}$ represent the largest cohort study thus far to evaluate the impact of diabetes on NLR and its relationship to angiographically proven CAD. They showed that NLR is increased among diabetic patients and is independently associated with the prevalence and severity of CAD in the same population. In current study, the mean NLR values were significantly higher in CAD+DM group than patients with diabetic microvascular complications. But, there was no statistically significant difference in the mean NLR values between CAD group and CAD+DM group. NLR has emerged from among inflammatory parameters as a potential indicator of vascular complications and poorer outcome in patients with diabetes ${ }^{30}$. Accumulating data results and future studies may be helpful in determining in risk stratification for cardiovascular diseases ${ }^{27}$.

NLR itself may not give sufficient information to clinicians about the chronic inflammatory disease state of the patient ${ }^{25}$. Results of study demonstrate a possible association of subclinical inflammation with the development of complications in T2DM. NLR are independent indicators for other well-known inflammatory markers as CRP, ESR and fibrinogen, inflammation in development of complications in T2DM. NLR values in prediction of complications in T2DM are a useful parameter. During complications of T2DM, NLR may be useful used as an easily measurable, noninvasive, available and cost-effective parameter with high prognostic accuracy in clinical practice. Detailed studies are particularly required regarding the association of NLR with individual microvascular and macrovascular complications of T2DM.

Ethics Committee Approval: Ethics committee approval was received for this study from Istanbul University, Cerrahpasa Medical Faculty (Approvel Date: February 4 ${ }^{\text {th }}$, 2016; Approval No: 44313).

Informed Consent: Informed consent was obtained from the patient who paticipated in this study.

\section{REFERENCES}

1. Donath MY, Shoelson SE. Type 2 diabetes as an inflammatory disease. Nat Rev Immunol. 2011; 11:98-107.
2. Sargın MA, Yassa M, Taymur BD, Celik A, Ergun E, Tug N. Neutrophil-to lymphocyte and platelet-to-lymphocyte ratios: are they useful for predicting gestational diabetes mellitus during pregnancy? Ther Clin Risk Manag. 2016; 12:657-65.

3. Yilmaz H, Ucan B, Sayki M, Unsal I, Sahin M, Ozbek M, et al. Usefulness of the neutrophil-to-lymphocyte ratio to prediction of type 2 diabetes mellitus in morbid obesity. Diabetes Metab Syndr. 2015; 9:299-304.

4. Ayhan H, Kasapkara HA, Aslan AN, Durmaz T, Keleş $T$, Akçay $M$, et al. Relationship of Neutrophil-toLymphocyte Ratio with Aortic Stiffness in Type 1 Diabetes Mellitus. Can J Diabetes. 2015; 39: 317-21.

5. Demirtas L, Degirmenci H, Akbas EM, Ozcicek A, Timuroglu A, Gurel A, et al. Association of hematological indicies with diabetes, impaired glucose regulation and microvascular complications of diabetes. Int J Clin Exp Med. 2015; 8: 11420-7.

6. Tanındı A, Erkan AF, Alhan A, Töre HF. Arterial stiffness and central arterial wave reflection are associated with serum uric acid, total bilirubin, and neutrophil-tolymphocyte ratio in patients with coronary artery disease. Anatol J Cardiol. 2015; 15: 396-403.

7. Ciray H, Aksoy AH, Ulu N, Cizmecioglu A, Gaipov A, Solak Y. Nephropathy, but not Angiographically Proven Retinopathy, is Associated with Neutrophil to Lymphocyte Ratio in Patients with Type 2 Diabetes. Exp Clin Endocrinol Diabetes. 2015; 123: 267-71.

8. Bakirci EM, Demirtas L, Degirmenci H, Topcu S, Demirelli S, Hamur H, et al. Relationship of the total atrial conduction time to subclinical atherosclerosis, inflammation and echocardiographic parameters in patients with type 2 diabetes mellitus. Clinics (Sao Paulo). 2015; 70: 73-80.

9. Ulu SM, Dogan M, Ahsen A, Altug A, Demir K, Acartürk G, et al. Neutrophil-tolymphocyte ratio as a quick and reliable predictive marker to diagnose the severity of diabetic retinopathy. Diabetes Technol Ther. 2013; 15: 942-7.

10. Akbas EM, Demirtas L, Ozcicek A, Timuroglu A, Bakirci EM, Hamur H, et al. Association of epicardial adipose 
tissue, neutrophil-to-lymphocyte ratio and platelet-to-lymphocyte ratio with diabetic nephropathy. Int J Clin Exp Med. 2014; 7 : 1794-801.

11. Zhang J, Gong F, Li L, Zhao M, Song J. Diabetes mellitus and the neutrophil to lymphocyte ratio predict overall survival in non-viral hepatocellular carcinoma treated with transarterial chemoembolization. Oncol Lett. 2014; 7: 1704-10.

12. Yilmaz H, Celik HT, Namuslu M, Inan O, Onaran Y, Karakurt F, et al. Benefits of the neutrophil-to-lymphocyte ratio for the prediction of gestational diabetes mellitus in pregnant women. Exp Clin Endocrinol Diabetes. 2014; 122: 39-43.

13. Kalaycioğlu E, Gökdeniz T, Aykan AC, Gül I, Boyac1 F, Gürsoy OM, et al. Comparison of neutrophil to lymphocyte ratio in patients with coronary artery ectasia versus patients with obstructive coronary artery disease. Kardiol Pol. 2014; 72: 372-80.

14. Öztürk ZA, Kuyumcu ME, Yesil Y, Savas E, Yıldız H, Kepekçi Y, et al. Is there a link between neutrophil-lymphocyte ratio and microvascular complications in geriatric diabetic patients? J Endocrinol Invest. 2013; 36: 593-9.

15. Lee GK, Lee LC, Chong E, Lee CH, Teo SG, Chia BL, et al. The long-term predictive value of the neutrophil-tolymphocyte ratio in Type 2 diabetic patients presenting with acute myocardial infarction. QJM. 2012; 105: 1075-82.

16. Azab B, Daoud J, Naeem FB, Nasr R, Ross J, Ghimire P, et al. Neutrophil-tolymphocyte ratio as a predictor of worsening renal function in diabetic patients (3-year follow-up study). Ren Fail. 2012; 34: 571-6.

17. Lou M, Luo P, Tang R, Peng Y, Yu S, Huang W, et al. Relationship between neutrophil-lymphocyte ratio and insulin resistance in newly diagnosed type 2 diabetes mellitus patients. BMC Endocr Disord. 2015; 15: 9.

18. American Diabetes Association. Diagnosis and classification of diabetes mellitus. Diabetes Care 2010 Jan; 33 (Supplement 1): S62-S69.

19. Chobanian AV, Bakris GL, Black HR, Cushman WC, Green LA, Izzo JL Jr, et al.; Joint National Committee on Prevention, Detection, Evaluation, and Treatment of High Blood Pressure.
National Heart, Lung, and Blood Institute; National High Blood Pressure Education Program Coordinating Committee. Seventh report of the Joint National Committee on Prevention, Detection, Evaluation, and Treatment of High Blood Pressure. Hypertension 2003; 42: 120652.

20. Lou M, Luo P, Tang R, Peng Y, Yu S, Huang W, et al. Relationship between neutrophil-lymphocyte ratio and insulin resistance in newly diagnosed type 2 diabetes mellitus patients. BMC Endo Disord 2015; 15: 9.

21. Fawwad A, Butt AM, Siddiqui IA, Khalid M, Sabir R, Basit A. Neutrophil-tolymphocyte ratio and microvascular complications in subjects with type 2 diabetes: Pakistan's perspective. Turk J Med Sci. 2018; 48: 157-161.

22. Moursy EY, Megallaa MH, Mouftah RF, Ahmed SM. Relationship between neutrophil lymphocyte ratio and microvascular complications in Egyptian patients with type 2 diabetes. Am J Intern Med 2015; 3: 250-5.

23. Yue S, Zhang J, Wu J, Teng W, Liu L, Chen L. Use of the Monocyte-toLymphocyte Ratio to Predict Diabetic Retinopathy. Int J Environ Res Public Health. 2015; 12: 10009-19.

24. Chittawar S, Dutta D, Qureshi Z, Surana V, Khandare S, Dubey TN. Neutrophillymphocyte Ratio is a Novel Reliable Predictor of Nephropathy, Retinopathy, and Coronary Artery Disease in Indians with Type-2 Diabetes. Indian $\mathbf{J}$ Endocrinol Metab. 2017; 21: 864-70.

25. Tanındı A, Erkan AF, Ekici B, Alhan A, Töre HF. Neutrophil to lymphocyte ratio is associated with more extensive, severe and complex coronary artery disease and impaired myocardial perfusion. Turk Kardiyol Dern Ars. 2014; 42: 125-30.

26. Pearson TA, Mensah GA, Alexander RW, Anderson JL, Cannon RO 3rd, Criqui M, et al. Markers of inflammation and cardiovascular disease: application to clinical and public health practice: A statement for healthcare professionals from the Centers for Disease Control and Prevention and the American Heart Association. Circulation 2003; 107: 499511.

27. Koza Y, Taş MH, Simşek Z, Ateş ES. The relationship between neutrophil-tolymphocyte ratio and coronary artery 
disease. Anadolu Kardiyol Derg. 2014; 14: 99-101.

28. Gabbasov Z, Kozlov S, Melnikov I, Byazrova S, Saburova O, Prokofieva L, et al. Novel Biomarkers for Coronary Restenosis Occurrence After DrugEluting Stent Implantation in Patients With Diabetes Having Stable Coronary Artery Disease. Clin Appl Thromb Hemost. 2018 Jan 1:1076029618771752. doi: 10.1177/1076029618771752. [Epub ahead of print].

29. Kim BJ, Cho SH, Cho KI, Kim HS, Heo $\mathrm{JH}$, Cha TJ. The Combined Impact of Neutrophil-to-Lymphocyte Ratio and Type 2 Diabetic Mellitus on Significant Coronary Artery Disease and Carotid Artery Atherosclerosis. J Cardiovasc Ultrasound. 2016; 24: 115-22.

30. Verdoia M, Schaffer A, Barbieri L, Aimaretti G, Marino P, Sinigaglia F, et al.; Novara Atherosclerosis Study Group (NAS). Impact of diabetes on neutrophilto-lymphocyte ratio and its relationship to coronary artery disease. Diabetes Metab. 2015; 41: 304-11. 